удк 378.091.33-021.464:37.11.3-051]:796.421

Інна Павленко

Сумський державний педагогічний університет імені А. С. Макаренка ORCID ID 0000-0002-1668-9119

Ольга Сидоренко

Сумський державний педагогічний університет імені А. С. Макаренка ORCID ID 0000-0002-9598-4617

Олег Шумаков

Сумський державний педагогічний університет імені А. С. Макаренка

ORCID ID 0000-0002-4801-0967

DOI 10.24139/2312-5993/2020.08/252-263

\title{
УДОСКОНАЛЕННЯ ФІЗИЧНОЇ ПІДГОТОВЛЕНОСТІ МАЙБУТНІХ УЧИТЕЛІВ ЗАСОБАМИ САМОСТІЙНИХ ЗАНЯТЬ ВЗ ОЗДОРОВЧОЇ ХОДЬБИ
}

у статті розглянуто проблему вдосконалення фрізичної підготовленості майбутніх учителів засобами самостійних занять із оздоровчої ходьби. Із метою доцільності застосування самостійних занять оздоровчою ходьбою в процесі професійної підготовки в закладах вищої педагогічної освіти проведено анкетування студентів навчально-наукового інституту педагогіки $і$ психології. Розроблено експериментальну програму самостійних занять оздоровчою ходьбою, яка складається з трьох етапів: підготовчий етап - освоєння техніки оздоровчої ходьби; етап підвищення швидкості ходьби і розвитку фізичних якостей; етап удосконалення елементів ходьби і підвищення функціональних можливостей організму.

Ключові слова: заклади вищої педагогічної освіти, майбутні вчителі, оздоровча ходьба, самостійні заняття, студенти, фрізичне виховання.

Постановка проблеми. Професійна діяльність майбутніх учителів містить обов'язковий фізичний компонент, оскільки саме студенти закладів вищої педагогічної освіти, вступаючи на ниву професійного життя, повинні мати відповідну фізичну та теоретичну підготовленість у питаннях зміцнення і збереження здоров'я учасників освітнього процесу.

Навчальна дисципліна «Фізичне виховання», яка викладається в закладах вищої педагогічної освіти, $\epsilon$ основою формування здоров'я майбутніх учителів, їхньої фізичної підготовленості і фізичної досконалості.

Однак, аналізуючи сучасні наукові дослідження в галузі професійної педагогічної освіти та фізичної культури і спираючись на власний досвід, можемо зазначити, що, наразі, є суттєві бар'єри для поширення фізичної культури, зокрема: недолік фінансування, слабка пропаганда здорового способу життя, невключення дисципліни «Фізичне виховання», як 
обов'язкової дисципліни, у навчальні плани закладів вищої педагогічної освіти. Усе це перешкоджає реалізації освітніх стратегій молоді в напрямі фізичної підготовленості. Особливо актуальною є зазначена проблема для студентів закладів вищої педагогічної освіти, оскільки майбутні вчителі несуть відповідальність за здоров'я своїх вихованців.

Відомо, що найбільш сприятливими для збереження здоров'я й фізичної підготовленості студентів є триразові заняття по дві навчальні години з фізичного виховання на тиждень, що зумовлено фізіологічними особливостями організму людини. Проте реалії сьогодення не дають змоги більшості закладам вищої педагогічної освіти планувати таку кількість годин, навіть чотири години занять на тиждень деякі університети вважають зайвими та, плануючи одноразові (дві години) заняття на тиждень, заощаджують на здоров'ї студентів, що призводить до поглиблення проблеми.

Дефіцит рухової активності студентів вимагає від викладачів подальшого пошуку прихованих резервів і способів оптимізації навчального процесу з фізичного виховання. Одним із таких резервів $\epsilon$ самостійна робота студентів, що, за неможливості повністю замінити практичні заняття під контролем викладача, певною мірою доповнює обсяг фізичних навантажень різної спрямованості.

Суттєвим підгрунтям необхідності такої форми роботи є підвищення фізичної підготовленості майбутніх учителів та набуття ними навичок самостійної роботи над власним здоров'ям і здоров'ям своїх вихованців, що є необхідною умовою успішної професійної діяльності.

Отже, проблема ефективного організаційно-методичного забезпечення процесу вдосконалення фізичної підготовленості майбутніх учителів засобами самостійних занять із оздоровчої ходьби, наразі, $\epsilon$ актуальною й потребує нагального вирішення.

Аналіз актуальних досліджень. Низка вітчизняних і зарубіжних науковців вивчають проблему організаційно-методичного забезпечення самостійних занять студентів закладів вищої педагогічної освіти.

В. Акимова презентує форми і методи організації самостійної роботи студентів із фізичного виховання; С. Королінська - організацію самостійної роботи студентів із фізичного виховання (Акімова, 2012, с. 6); О. Мілаєв досліджує ставлення студентів до занять фізичною культурою; С. Кудін вплив занять фізичними вправами на психічне здоров'я студентів; О Непша, Г. Суханова - формування у студентів мотиваційно-ціннісного ставлення до фізичної культури. 
На думку С. Атаманюк, О. Кириченко, Р. Раєвського, найбільший оздоровчий ефект відбувається під час використання циклічних засобів аеробного спрямування, таких як ходьба і біг (Атаманюк, 2014, с. 206).

Оздоровча ходьба - це найдоступніший і найпростіший вид фізичної активності і $€$ обов'язковим початковим етапом організації самостійних занять, оскільки під час ходьби навантаження на ноги в 2 рази менше, ніж під час бігу. Ходьбою можна займатися і на вулиці, і в парку, і в лісі. Під час ходьби активно працюють усі м'язові групи. У сучасних наукових дослідженнях Н. Базилевич, Т. Овчаренко та ін. доведено оздоровчий вплив ходьби на серцево-судинну, дихальну та нервову системи організму людини, обмін речовин, загальний стан здоров'я, розроблено рекомендації щодо техніки оздоровчої ходьби (Базилевич, 2019; Овчаренко, 2002).

Низка науковців зазначає, що ходьба забезпечує високе функціональне навантаження та тренування, покращує роботу серцевосудинної і дихальної систем. Порівняно зі звичайною ходьбою, оздоровча ходьба характеризується більш високим темпом, більш ритмічними, тривалими і жвавими рухами, які змушують працювати серце й легені інтенсивніше, постачаючи кисень м'язам. Швидкість у прискореному варіанті може досягати 7 км/год, у роботу включаються м'язи гомілки й таза, стопа активно відштовхується від опори за рахунок згинання в кульшовому суглобі (Донской, 1983, с. 83).

Отже, наведені дані підтверджують важливість застосування самостійної роботи з використанням засобів оздоровчої ходьби для покращення навчального процесу з фізичного виховання та збільшення рухової активності студентів. Самостійні заняття оздоровчою ходьбою $\epsilon$ суттєвою складовою частиною навчального процесу 3 фізичного виховання, вона значно підвищує рухову активність студентів, надає студентам навички самостійної роботи з покращення власного здоров'я й фізичної підготовленості, необхідні для майбутньої професійній діяльності. Індивідуальні (домашні) завдання $\epsilon$ необхідною умовою виконання самостійної роботи, причому головний критерій контролю за виконанням самостійної роботи студентів - це виконання відповідних тестів, а підстава для планування й складання домашніх завдань - визначення недоліків у загальній і спеціальній фізичній підготовленості студентів.

Робота з планування самостійної роботи студентів повинна супроводжуватися відповідним науково-методичним забезпеченням у вигляді кафедральної програми самостійних занять, індивідуальних завдань і відповідної системи тестування, розроблених провідними фахівцями кафедр 
фізичного виховання з урахуванням специфіки навчального відділення та його матеріальної бази, стану фізичної підготовленості контингенту студентів, завдань, особливостей і оздоровчих можливостей обраного виду спорту.

Мета дослідження - експериментально перевірити вплив самостійних занять оздоровчою ходьбою на підвищення фізичної підготовленості майбутніх учителів.

Відповідно до мети сформульовано завдання дослідження:

1. Проаналізувати стан досліджуваної проблеми у психологопедагогічний і спеціальній літературі.

2. Теоретично обґрунтувати доцільність застосування занять оздоровчою ходьбою в процесі фізичного виховання студентів закладів вищої педагогічної освіти.

3. Експериментально перевірити ефективність впливу занять оздоровчою ходьбою на підвищення фізичної підготовленості майбутніх учителів

Методи дослідження. Для вирішення поставлених завдань нами були використані такі методи: теоретичний аналіз і узагальнення наукової літератури із зазначеної проблеми, спостереження, анкетування, тестування, педагогічний експеримент, математична обробка даних.

Дослідження проводилось на базі Сумського державного педагогічного університету імені А. С. Макаренка. У ньому взяли участь 106 студентів 3-4 курсів навчально-наукового Інституту педагогіки та психології.

Виклад основного матеріалу. Навчання в закладах вищої освіти складна та напружена розумова праця, яка часто виконується в умовах дефіциту часу на тлі зниження рухової активності. Заняття фізичною культурою для студентів слід розглядати не тільки як засіб зміцнення здоров'я та різнобічного фізичного розвитку організму, але і як засіб активного відпочинку, відновлення після напруженої розумової праці й підготовки до наступних занять.

В організації і проведенні самостійних занять рекомендується врахувати особливості педагогічної професії, яку здобувають студенти, інтереси та бажання, доступність фізичних вправ, підсумковий ефект від занять, який проявляється у зміцненні здоров'я і зниженні захворюваності тих, хто займається, у поліпшенні їхнього фізичного розвитку й фізичної підготовленості а, також, у підвищенні навчальної успішності студентів. Також самостійна робота сприяє гармонійному розвиткові особистості студентів, формуванню морально-вольових якостей.

На думку науковців (Павленко, 2018; Суббота, 2011) самостійні заняття фізичною культурою повинні передбачати розв'язання таких завдань: 
- фізичне вдосконалення та самовиховання потреби в регулярних заняттях фізичними вправами;

- уміння застосовувати передові методи та засоби оздоровчої фізичної культури для профілактики захворювань та зміцнення здоров'я шляхом упровадження фізкультурно-оздоровчих заходів;

- уміння розвивати психофізичні якості відповідно до специфічних вимог майбутньої професійної діяльності.

Самостійні заняття фізичними вправами рекреативної спрямованості для студентів закладів вищої освіти $€$ засобом розвантаженням нервової системи, що переключає студентів із розумової праці на фізичну.

Самостійні заняття проводять студенти у вільний від навчання час на основі повної добровільності й ініціативи (за бажанням), або як завдання викладача (домашнє завдання). Заняття проводяться 3-4 рази на тиждень по 30-40 хвилин, їх скасовують у дні, коли за розкладом $\epsilon$ навчальні заняття з фізичного виховання. Також, у певний час, самостійні заняття можна замінити на участь у змаганнях, одноденних туристичних походах, лижних або велосипедних прогулянках тощо.

Самостійні заняття впродовж дня проводяться для забезпечення працездатності, відновлення після певного навантаження, психорегуляції та корекції емоційного стану.

У режимі дня студентів вони мають такі форми:

- ранкова гігієнічна гімнастика;

- фізичні вправи впродовж навчального дня;

- самостійні тренувальні заняття.

Заняття оздоровчою ходьбою мають певні переваги серед інших видів оздоровчих самостійних занять, оскільки оздоровча ходьба $\epsilon$ найбільш доступним видом самостійних занять, а для самих занять необхідно лише бажання розпочати рух.

Незважаючи на гіподинамію та ії наслідки (порушення функцій організму, опорно-рухового апарату, кровообігу, дихання, травлення), через обмеження рухової активності і зниження сили скорочення м'язів, що створюють серйозну небезпеку для здоров'я сучасної людини, студенти не завжди знаходять час для оздоровчого тренування. Однією 3 особливостей занять ходьбою є можливість частину фізичних навантажень природньо включати в режим дня: ходьба на заняття і назад, прогулянки, подолання швидким кроком невеликих відстаней протягом дня. Незважаючи на те, що для цілеспрямованого тренування серцево-судинної системи обов'язкові безперервність і високий темп рухів, ходьба і на 
короткі дистанції приносить свою користь, передусім тим, що допомагає відпрацьовувати швидкість ходьби, яка в наступному дасть можливість збільшувати навантаження. Також заняття оздоровчою ходьбою не вимагають спеціальної екіпіровки і виглядають досить природно.

Можливість регулювати навантаження під час ходьби сприяє заохоченню студентів, які мають низький рівень фізичної підготовленості, до рухової активності.

Під час ходьби є можливість поєднувати творчу (розумову) діяльність і ходьбу. Посилена робота серця і легенів під час ходьби посилює кровообіг в усьому тілі, у тому числі і в мозку. Активніша циркуляція крові приносить більше кисню і глюкози, відповідно, мозок отримує більше ресурсів для роботи. Ходьба - високоавтоматизована навичка, у процесі якої стопа проноситься низько над поверхнею землі, приземлення, починаючи з п'яти, значно знижує небезпеку травматизму. До того ж, заняття оздоровчою ходьбою не потребують напруженої уваги як при інших видах рухової активності. Саме ходьба надає сприятливу можливість одночасно поєднувати творчу роботу розуму і рух набагато більшою мірою, ніж під час занять іншими видами фізкультурної діяльності.

Швидка ходьба - один із найпростіших і найдоступніших способів зняття психологічної напруги, набуття «цілющої» фізичної втоми. Під час різних депресивних станів ходьба також може зіграти роль антидепресанту. Науковці пояснюють ефект поліпшення психологічного стану під час вправ на витривалість виділенням В організмі гормону ендорфіну, «гормону задоволення», який сприятливо впливає на психіку людини.

Ходьба зміцнює зв'язковий апарат і кісткову тканину, тим самим знижуючи хворобливі відчуття в суглобах і ризик переломів кісток.

Оскільки кожна людина має різні антропометричні показники та різний рівень розвитку рухових здібностей і фізичних якостей, то це в сукупності накладає індивідуальний відбиток на всі прийоми ходьби, що називаються ходою.

Заняття оздоровчою ходьбою проводяться в спортивних приміщеннях і на відкритих майданчиках, де $\epsilon$ можливість виконувати як спеціальні вправи з вивчення й засвоєння технічних прийомів оздоровчої ходьби, так і вправи загальнофізичної підготовки.

Наше дослідження присвячено розробці програми самостійних занять оздоровчою ходьбою для студентів 3-4 курсів із урахуванням навчального плану з дисципліни «Фізичне виховання», яким передбачено 2 академічних години на тиждень занять із фізичного виховання. 
Із метою виявлення рівня усвідомлення цінностей фізичної культури, значення самостійних оздоровчих занять, розуміння впливу оздоровчої ходьби на організм людини, дотримання здорового способу життя нами була розроблена анкета, до якої увійшло 12 питань:

1. Чи має для Вас значення власний стан здоров'я? (так; ні; не зовсім; інша відповідь).

2. Чи вважаєте Ви себе здоровою людиною? (так; ні; не зовсім; інша відповідь).

3. Чи достатньо Вам одного заняття на тиждень із фізичного виховання для фізичного вдосконалення? (так; ні; не зовсім; інша відповідь).

4. Скільки годин на тиждень Ви хотіли би займатися фізичним вихованням? (власна відповідь).

5. Чи впливає фізичне навантаження на покращення роботи огранів i систем людини (так; ні; не знаю; інша відповідь).

6. Скільки годин на тиждень Ви займаєтесь самостійною фізичною підготовкою? (один раз 1 годину; два рази 3 години; три рази 4 години; не займаюсь).

7. Чи вважаєте Ви оздоровчу ходьбу доступним видом самостійних занять у порівнянні з іншими видами? (так, бо непотрібно витрачати час та кошти на відвідування спортивних залів; так, бо непотрібно спеціальної екіпіровки для занять; так, бо ходьба $є$ найменш травматичним із видів фізичних навантажень; так, бо можна самому вибирати час для занять).

8. Чи займаєтеся Ви оздоровчою ходьбою? (займаюсь раз на тиждень; займаюсь тричі на тиждень; займаюсь щодня; ходжу пішки на навчання 30 хв. щодня).

9. Чи бажаєте Ви підвищувати рівень фізичного розвитку свого організму? (так; ні; хочу підвищити; інша відповідь).

10. Чи вважаєте Ви свою ходу правильною і красивою? (так; ні; хочу змінити свою ходу на краще; інша відповідь).

11. Скільки часу в день Ви приділяєте фізичним навантаженням для підтримки свого здоров'я? (30 хв.; 60 хв.; 90 хв.; інша відповідь).

12. Які перешкоди заважають Вам займатися самостійними заняттями оздоровчою ходьбою? (відсутність часу і умов для занять; власна лінь; побутові умови; інша відповідь).

Результатати проведеного анкетування свідчать про те, що 74,5 \% респондентів вважають, що стан власного здоров'я має для них велике значення, але лише 25,4\% абсолютно ним задоволені. Усього $17,9 \%$ 
респондентів приділяють увагу підтримці власного здоров'я більше години на день, 19,8 \% відводять на це від 30 до 60 хвилин, 32,07 \% - від 15 до 20 хвилин на день, а у 21,7 \% зовсім немає на це часу. При цьому 86,8 \% респондентів позитивно оцінюють значення самостійних занять оздоровчою ходьбою, фізичного навантаження, фізичних вправ, а 37,7 \% студентів систематично самостійно займаються. На питання «Скільки годин на тиждень Ви займаєтеся самостійною фізичною підготовкою?» і «Скільки часу в день ви приділяєте фізичним навантаженням для підтримки свого здоров'я?», 22,6\% респондентів вважають для себе оптимальним режим рухової активності, що становить більше 10 годин на тиждень, але самостійно займаються оздоровчою ходьбою лише 14,2 \% респондентів. При цьому, 32,1\% студентів визначили оптимальним 4-6 годинний тижневий режим рухової активності, але використовують його всього $16,03 \%$ респондентів, тоді як 38,7 \% опитаних вважають достатнім 2-4-х годинний тижневий режим рухової активності, але на практиці застосовують даний режим 49,1 \% студентів.

Серед причин, що не дозволяють більшості респондентів певною мірою займатися фізичними вправами і вести здоровий спосіб життя, перше місце $(49,1$ \% респондентів) займає відсутність часу і умов для занять, друге місце (29,2 \% респондентів) займає власна лінь, третє місце (13,2 \% респондентів) займають побутові умови. На четвертому місці - група студентів, які вважають, що в заняттях фізичною культурою немає необхідності.

Ураховуючи дані проведеного анкетування, нами була розроблена експериментальна програма для самостійних занять оздоровчою ходьбою. Зміст програми містить три етапа:

1. Підготовчий етап - освоєння техніки оздоровчої ходьби.

2. Етап підвищення швидкості ходьби і розвитку фізичних якостей.

3. Етап удосконалення елементів ходьби і підвищення функціональних можливостей організму.

На першому етапі увага актуалізувалася на вивченні техніки оздоровчої ходьби, перш за все - положенні стоп, тіла, правильному диханню. Середня довжина оздоровчого кроку приймалася в межах 70-80 см. Для успішного оволодіння технікою оздоровчої ходьби на першому етапі пропонували студентам включати в руховий режим обов'язкові заняття ранковою гімнастикою, фізкультурні паузи в режимі дня тощо. Розпочинати заняття, пропонували з розроблених комплексів підготовчих вправ. Особлива увага приділялася використанню методів самоконтролю. На першому етапі експериментальної програми дотримувалися помірних навантажень. 
На етапі підвищення швидкості ходьби і розвитку фізичних якостей застосовувалися підготовчі та імітаційні вправи, вправи з елементами техніки спортивної ходьби, прискорена ходьба в змагальному темпі. Прискорена ходьба при відповідній швидкості (до 6,5 км/год) досягала зони тренуючого режиму (ЧСС 120-130 уд/хв). На другому етапі експериментальної програми заняття будували за загальноприйнятою у фізичному вихованні структурою втягування в режим навантаження на початку заняття, виконання основних завдань тренування в середині і поступове зниження навантаження в кінці. Поточним показником оцінки навантаження слугували контрольні дані частоти серцевих скорочень - верхня максимально допустима межа (чСС 140-160 уд/хв). На етапі розвитку фізичних якостей і підвищення швидкості ходьби вирішували завдання адаптації організму до зростаючих навантажень, удосконалення фізичної підготовленості, і на цьому фоні поступове підвищення швидкості. Для студентів із високими показниками фізичної підготовленості швидкість ходьби підвищували також за допомогою доступного навантаження до 10-11 км на годину як найбільш оптимального фізичного навантаження на організм таких студентів.

Для розвитку фізичних якостей складалися індивідуальні комплекси вправ.

Tретіŭ етап експериментальної програми містить різноманітні варіанти оздоровчої ходьби для вдосконалення техніки пересування: ходьбу по твердому покритті, ходьбу по пересіченій місцевості; ходьбу з подоланням перешкод. Здійснювався туристичний похід 10-15 км із зупинками на відпочинок. Для підвищення функціональних можливостей організму використовувалися загальнорозвивальні вправи та вправи на розвиток гнучкості, а також відновлювальна ходьба. Темп виконання вправ на третьому етапі був помірний, оскільки ми сталили переважно оздоровчі завдання.

Для перевірки ефективності розробленої програми самостійних занять оздоровчою ходьбою ми провели контроль морфо-функціонального стану і розвитку фізичних якостей студентів. Для цього використовували комплекс морфологічних характеристик, показників стану серцево-судинної та дихальної систем, а також тестових вправ (тест Купера, спортивна ходьба 2000 м, біг на 100 м і 1000 м, згинання та розгинання рук в упорі лежачі на підлозі тощо), а також перевірили антропометричні дані.

Отримані дані свідщать про те, що регулярне і тривале виконання вправ аеробного режиму, а саме оздоровчої ходьби, призвело до підвищення функціональних можливостей організму студентів і підвищення рівня їхньої фізичної підготовленості. Систематичні (не рідше 
Педагогічні науки: теорія, історія, інноваційні технології, 2020, № 8 (102)

2 разів на тиждень) самостійні заняття з оздоровчої ходьби мають суттєве значення для зміцнення здоров'я та підвищення опору організму дії несприятливих чинників довкілля, про що свідчить зниження захворюваності студентів протягом навчального року.

Висновки та перспективи подальших наукових розвідок. Отже, аналіз результатів дослідження дає підстави зробити висновки про те, що самостійна робота є суттєвою складовою освітнього процесу з фізичного виховання в педагогічних закладах вищої освіти. Використання засобів оздоровчої ходьби значно підвищує рухову активність студентів, покращує їхню фізичну підготовленість, формує навички самостійної роботи зі збереження і зміцнення власного здоров'я та здоров'я всіх учасників освітнього процесу, необхідні для майбутньої професійній діяльності.

Використання розробленої програми самостійних занять оздоровчою ходьбою дозволить оптимізувати освітній процес із фізичного виховання в педагогічних закладах вищої освіти.

Перспективи подальших наукових розвідок із заданої проблеми можуть бути спрямовані на розробку педагогічних умов використання самостійних занять із оздоровчої ходьби в процесі професійної підготовки в закладах вищої освіти різного рівня акредитації.

\section{ЛІТЕРАТУРА}

Акимова, В. А., Турчина, Н. І., Черняєв, Е. Г. (2012). Форми і методи організації самостійної роботи студентів з фізичного виховання. Фізичне виховання в контексті сучасної освіти: матеріали VII Всеукр. наук.-метод. конф. К.: НАУ (Akymova, V. A., Turchyna, N. I., Cherniaiev, E. H. (2012). Forms and methods of organizing independent work of students in physical education. Physical education in the context of modern education: materials of the VII All-Ukrainian scientific-method. conf. K.: NAU).

Атаманюк, С., Кириченко, О. (2014). Методика застосування оздоровчої ходьби для студентів спеціальної медичної групи. Спортивний вісник Придніпров'я, 1, 204207 (Atamaniuk, S., Kyrychenko, 0. (2014). Methods of using health walking for students of a special medical group. Sports Bulletin of the Prydniprovia, 1, 204-207).

Базилевич, Н. О., Тонконог, О. С. (2019). Оздоровча ходьба як засіб підвищення функціональних можливостей студентів вищих педагогічних навчальних закладів. Науковий часопис Національного педагогічного університету імені М. П. Драгоманова. Серія 15: Науково-педагогічні проблеми фрізичної культури (фрізична культура і спорт), Вип. 3к (110), 64-68 (Bazylevych, N. O., Tonkonoh, 0. S. (2019). Health walking as a means of increasing the functionality of students of higher pedagogical education institutions. Scientific journal of the National Pedagogical University named after M. P. Drahomanov. Series 15: Scientific and pedagogical problems of physical culture (physical culture and sports), Vol. 3K (110), 64-68).

Донской, Д. Д. (1983). Методические рекомендации по технике оздоровительной ходьбы и оздоровительного бега. М.: ФиС (Donskoi, D. D. (1983). Methodological recommendations on the technique of health walking and health running. M.: FiS). 
Євдокимов, В. І. (2004). Самостійна робота студентів. Х.: Вид-во ХДгУ (Yevdokymov, V. I. (2004). Independent work of students. Kh.: Published by KSU).

Королінська, С. В. (2006). Аналіз соціально-педагогічних основ формування потреб в самостійних заняттях фізичною культурою у студентів НфаУ. У С. С. Єрмаков, Педагогіка, психологія та медико-біологічні проблеми фізичного виховання і cпopmy, 12, 93-96 (Korolinska, S. V. (2006). Analysis of socio-pedagogical bases of formation of needs in independent physical education classes for NfaU students. In S. S. Yermakov, Pedagogy, Psychology and Medical and Biological Problems of Physical Education and Sports, 12, 93-96).

Овчаренко, Т. Г. (2002). Система самостійної роботи студентів у курсі «Теорія та методика фрізичного виховання». Луцьк: РВВ “Вежа" Волин. держ. ун-т ім. Лесі Українки (Ovcharenko, Т. Н. (2002). The system of independent work of students in the course "Theory and methods of physical education". Lutsk).

Павленко, І. О. (2018). Тенденції реалізації фізичного потенціалу студентів педагогічних спеціальностей. Педагогічні науки: теорія, історія, інноваційні технології, 3 (77), 178-187 (Pavlenko, I. 0. (2018). Trends in the realization of the physical potential of students of pedagogical specialties. Pedagogical sciences: theory, history, innovative technologies, 3 (77), 178-187).

Суббота, Ю. В. (2011). Оздоровчі рухові програми самостійних занять фрізичною культурою і спортом: практ. посіб. для студ. вищих навч. закладів III-IV рівнів акредитації. К.: Кондор (Subbota, Yu. V. (2011). Wellness motor programs of independent physical culture and sports: practic. guide for students of higher education institutions of the III-IV levels of accreditation. K.: Condor).

\section{PEЗЮME}

Павленко Инна, Сидоренко Ольга, Шумаков Олег. Совершенствование физической подготовленности будущих учителей посредством самостоятельных занятий оздоровительной ходьбой.

В статье рассмотрена проблема совершенствования физической подготовленности будущих учителей посредством самостоятельных занятий оздоровительной ходьбой. С целью целесообразности применения самостоятельных занятий оздоровительной ходьбой в процессе профессиональной подготовки в учреждениях высшего педагогического образования проведено анкетирование студентов учебно-научного института педагогики и психологии. Разработана экспериментальная программа самостоятельных занятий оздоровительной ходьбой, которая состоит из трех этапов: подготовительный этап - освоение техники оздоровительной ходьбы; этап повышения скорости ходьбы и развития физических качеств; этап совершенствования элементов ходьбы и повышение функциональных возможностей организма.

Ключевые слова: высшие педагогические учебные заведения, будущие учителя, оздоровительная ходьба, самостоятельные занятия, студенты, физическое воспитание.

\section{SUM M ARY}

Pavlenko Inna, Sydorenko Olha, Shumakov Oleh. Improving physical fitness of future teachers by means of independent classes in health walking.

The article considers the problem of improving the physical fitness of future teachers by means of independent classes in health walking. Based on the analysis of scientific sources, the importance of independent work to improve the educational process of physical education and increase motor activity of students is indicated. 
The purpose of the article is to test experimentally the impact of independent walking classes on improving the physical fitness of future teachers.

In the study we used the following methods: theoretical analysis and generalization of scientific literature on this problem, observation, questionnaires, testing, pedagogical experiment, mathematical data processing.

The study was conducted on the basis of Sumy State Pedagogical University named after A. S. Makarenko. It involved 106 students of 3-4 courses of the Scientific and Educational Institute of Pedagogy and Psychology.

In order to identify the level of awareness of the values of physical culture, the importance of independent health classes, understanding the impact of walking on the human body, the idea of a healthy lifestyle, a survey of students of the Institute of Pedagogy and Psychology.

An experimental program of independent classes in health walking has been developed, which consists of three stages: preparatory stage - mastering the technique of health walking; stage of increasing walking speed and development of physical qualities; stage of improving the elements of walking and improving the functionality of the body.

The analysis of the research results gives grounds to conclude that independent work is an essential part of the educational process of physical education in institutions of higher pedagogical education.

The use of the developed program of independent classes in health walking will allow to optimize the educational process of physical education in institutions of higher pedagogical education.

Prospects for further research on this issue can be aimed at developing pedagogical conditions for the use of independent classes in walking in the process of training in higher education institutions of different levels of accreditation.

Key words institutions of higher pedagogical education, future teachers, health walking, independent classes, students, physical education.

\title{
Удк $378.14: 613$
}

Ірина Пальшкова

Південноукраїнський національний педагогічний університет імені К. Д. Ушинського

ORCID ID 0000-0002-6710-5232

DOI 10.24139/2312-5993/2020.08/263-276

\section{СТАН ПІДГОТОВЛЕНОСТІ МАЙБУТНІХ УЧИТЕЛІВ ПОЧАТКОВИХ КЛАСІВ ДО ЗДОРОВ'ЯЗБЕРЕЖУВАЛЬНОЇ ДІЯЛЬНОСТІ}

\begin{abstract}
Стаття присвячена дослідженню проблеми підготовленості майбутніх учителів початкових класів до здоров'язбережувальної діяльності. На підставі аналізу загальних теоретичних підходів до змісту здоров'язбережувальної діяльності подано авторську позицію щодо визначеного конструкта. Розглянуто структуру підготовленості майбутніх учителів початкових класів до здоров'язбережувальної діяльності, яка складається з мотиваційно-когнітивної, операційно-коригувальної й оцінно-рефлексивної складових із показниками, відповідно до яких було дібрано мануал діагностувальних методик.
\end{abstract}

